Memento 


\section{American Indies}

Series Editors: Gary Needham and Yannis Tzioumakis

Titles in the series include:

The Spanish Prisoner

Yannis Tzioumakis

9780748633685 (hbk)

9780748633692 (pbk)

Lost in Translation

Geoff King

9780748637454 (hbk)

9780748637461 (pbk)

Memento

Claire Molloy

9780748637713 (hbk)

9780748637720 (pbk)

Brokeback Mountain

Gary Needham

9780748633821 (hbk)

9780748633838 (pbk)

Forthcoming titles include:

Far From Heaven

Glyn Davis

9780748637782 (hbk)

9780748637799 (pbk) 


\title{
Memento
}

\author{
Glaire Molloy
}

Edinburgh University Press 
(C) Claire Molloy, 2010

Film stills (C) Newmarket / I Remember Productions

Edinburgh University Press Ltd

22 George Square, Edinburgh

www.euppublishing.com

Typeset in 11/13pt Monotype Baskerville by Servis Filmsetting Ltd, Stockport, Cheshire, and

printed and bound by CPI Antony Rowe, Chippenham and Eastbourne

A CIP record for this book is available from the British Library

ISBN 9780748637713 (hardback)

ISBN 9780748637720 (paperback)

The right of Claire Molloy

to be identified as author of this work

has been asserted in accordance with

the Copyright, Designs and Patents Act 1988. 